\title{
Controlled bioassay systems for determination of lethal infective doses of tissue homogenates containing Taura syndrome or white spot syndrome virus
}

\author{
Sarah Prior $^{1, *}$, Craig L. Browdy ${ }^{1}$, Eleanor F. Shepard ${ }^{1}$, Rolland Laramore ${ }^{2}$, \\ Pamela G. Parnell ${ }^{3}$ \\ ${ }^{1}$ South Carolina Department of Natural Resources, Marine Resources Research Institute, 217 Ft. Johnson Rd., Charleston, \\ South Carolina 29422, USA \\ ${ }^{2}$ Aquatic Animal Health Laboratory, Harbor Branch Oceanographic Institution Inc., 5600 US 1 North, Fort Pierce, \\ Florida 34946, USA \\ ${ }^{3}$ Clemson Veterinary Diagnostic Center, PO Box 102406, Columbia, South Carolina 29224-2406, USA
}

\begin{abstract}
In vivo bioassay is the predominant method for evaluating the infectivity of materials potentially harboring viable shrimp pathogens and determining the relative susceptibility of shrimp species to viral infections. A controlled bioassay system for white spot syndrome virus (WSSV) and Taura syndrome virus (TSV) was developed utilizing $260 \mathrm{ml}$ tissue culture flasks modified with an air exchange vent. Individual shrimp $(1.00 \pm 0.25 \mathrm{~g})$ were placed in separate flasks containing artificial seawater $\left(100\right.$ to $150 \mathrm{ml}$ ) and held in an incubator at $27^{\circ} \mathrm{C}$. After a $48 \mathrm{~h}$ acclimation period, shrimp were either injected intramuscularly with viral inoculum or exposed to virus-laden water. Water was exchanged and shrimp were fed a commercial food pellet daily except $24 \mathrm{~h}$ post-infection (p.i.). Bioassays were performed with serial dilutions of stock viral preparations and shrimp mortality was recorded for $7 \mathrm{~d}$ p.i. Mortality rates of test animals permitted the estimation of the lethal infective doses, $\mathrm{LD}_{50}$ and $\mathrm{LD}_{90}$. The $\mathrm{LD}_{50}$ of the TSV injection preparation was estimated at viral dilutions of 1:7.692 $\times 10^{7}$ (Trial 1) and 1:6.667 $\times 10^{7}$ (Trial 2). The $\mathrm{LD}_{50} \mathrm{~S}$ of 2 different WSSV injection preparations were estimated at $1: 4.444 \times 10^{6}$ and $1: 4.505 \times 10^{6}$. The $\mathrm{LD}_{50}$ for the TSV waterborne challenge was 1:9916 (Trial 1) and 1:15 710 (Trial 2) at $20^{\circ} \mathrm{C}$ and $1: 1272$ at $27^{\circ} \mathrm{C}$. A second waterborne TSV inoculum challenge at $27^{\circ} \mathrm{C}$ produced an $\mathrm{LD}_{50}$ of $1: 2857$. WSSV doses used in the waterborne challenge only reached $39 \%$ mortality, which did not allow for the estimation of effective lethal doses. Bioassay by injection proved to be a more reliable method of estimating viral infectivity compared to waterborne method. The dose-response curves developed can serve as a basis for controlled comparisons of relative levels of viral infectivity of specific tissue preparations and for controlled comparisons of relative susceptibility of shrimp species or stocks to viral pathogens.
\end{abstract}

KEY WORDS: TSV $\cdot$ WSSV $\cdot$ Bioassay $\cdot$ Shrimp $\cdot$ Litopenaeus vannamei

Resale or republication not permitted without written consent of the publisher

\section{INTRODUCTION}

Infectious diseases continue to represent one of the greatest constraints to the expansion and realization of aquaculture's full potential (Sinderman 1986, Plumb 1999). Viruses such as Taura syndrome virus (TSV) and white spot syndrome virus (WSSV) are highly pathogenic to shrimp and are widespread throughout the world in wild and cultured stocks (Lightner \& Redman 1991, Fulks \& Main 1992, Lightner 1996, 1999, Overstreet 1997). Shrimp cell culture is still in its developmental phase (Chen \& Kou 1989, Lu et al. 1995b, Kasornchandra \& Boonyaratpalin 1998, Loh et al. 1998). Therefore, in vivo bioassay remains an important tool for evaluating infectivity of material with unknown infective status and for detection of 
subclinical or carrier state infections (Brock 1992, Lightner 1996, Lightner \& Redman 1998, Durand et al. 2000, Lightner et al. 2001, Poulos et al. 2001). Diagnostic bioassays have been reported for a number of penaeid viruses including infectious hypodermal and hematopoetic necrosis virus (IHHNV) (Lightner et al. 1985), Baculovirus penaei (BP) (Overstreet et al. 1988), baculoviral midgut gland necrosis virus (BMNV) (Momoyama \& Sano 1988), TSV (Brock et al. 1995), and WSSV (Lightner 1999). Induction of experimental infections has been demonstrated to be an important tool for identifying and studying the pathogenicity of yellow head virus (YHV) (Lu et al. 1995a,b) and WSSV (Chou et al. 1995, Wang et al. 1999).

Current shrimp bioassay protocols are based on the administration of unquantified doses of infective material to a group of susceptible individuals (Brock \& Main 1994). WSSV DNA has been quantified using competitive polymerase chain reaction (PCR) and this method has been applied in risk assessment studies for the determination of relative viral load (Tang \& Lightner 2000, Lightner et al. 2001). Although the presence of viral DNA may correlate with infectivity, a system for quantitative comparison of viral infectivity is needed for true assessment of disease risk associated with various materials and carrier animals. The goals of this study were (1) to develop a controlled bioassay system for the estimation of lethal infective doses $\left(\mathrm{LD}_{50}\right.$ and $\mathrm{LD}_{90}$ ) (doses that kill $50 \%$ and $90 \%$ of the test animals, respectively) of TSV and WSSV in the Pacific white shrimp Litopenaeus vannamei, the cultured shrimp species in the southeastern United States, and (2) to evaluate 2 methods of exposure, namely, by injection of viral inoculum directly to the test animals and by incorporating the inoculum into the water (waterborne). The test procedures are intended to provide a convenient, rapid standard test method yielding a reasonably sensitive assay of viral infectivity and shrimp susceptibility.

\section{MATERIALS AND METHODS}

Bioassay requirements. Experimental shrimp: Specific Pathogen Free (SPF) Litopenaeus vannamei postlarvae were obtained from the Oceanic Institute's (OI) Kona facility in Hawaii. This SPF sentinel stock, which originated from Mexico in 1989 (Wyban et al. 1992), is maintained under biosecure conditions at OI, and serves as a reference stock for shrimp bioassays. Prior to challenge, shrimp were maintained on a commercial shrimp diet in $12 \mathrm{t}$ tanks in a greenhouse at the Waddell Mariculture Center, Bluffton, South Carolina. Shrimp selected for experiments were approximately uniform in size $(1.00 \pm 0.25 \mathrm{~g})$. For all assays con- ducted, negative controls (uninfected shrimp) originated from the same cohort.

Inoculum: Viral amplification: The original WSSV inoculum used for viral amplification was collected from cephalothoraxes of infected shrimp during a confirmed pond outbreak of WSSV in South Carolina in 1997. The Gulf Coast Research Laboratory (Ocean Springs, MS) supplied a TSV inoculum to the bioassay laboratory in 1997, which was used to produce TSV infected tissue by experimentally infecting SPF shrimp by injection. Viral amplifications were conducted in 381 polyethylene bins containing artificial salt water (Marine Environment ${ }^{\circledR}$ ) at 30 ppt. A polyester filter inoculated with nitrifying bacteria was placed directly above the air stone in each aquarium for biofiltration. The water was maintained between 25 and $29^{\circ} \mathrm{C}$, and a $10 \%$ water exchange was performed daily to remove molts, excess food and fecal materials. Twenty to thirty Litopenaeus vannamei juveniles were stocked into each aquarium and allowed to acclimate for $48 \mathrm{~h}$. The shrimp were fed to satiation with commercial pelleted shrimp feed during acclimation and after inoculation.

Shrimp were exposed to either WSSV or TSV by injection of inocula derived from the infected tissues. The head tissue was homogenized in TN buffer (20 mM Tris-HCL, $0.4 \mathrm{M} \mathrm{NaCl}, \mathrm{pH} 7.4)(1: 10 \mathrm{w} / \mathrm{v})$, and the supernatant was filtered with a $0.45 \mu \mathrm{m}$ filter after centrifugation as described below. The filtrate was injected intramuscularly between the second and third tail segment at $0.02 \mathrm{ml} \mathrm{g}^{-1}$ of shrimp immediately after preparation. Moribund individuals were collected and frozen at $-80^{\circ} \mathrm{C}$.

Inoculum preparation for injection assays: A large volume of stock inoculum was prepared from the frozen tissues prepared above. Infected head tissues were thawed and homogenized in chilled TN buffer using a blender. Dilution ratio was $10 \mathrm{ml}$ of $\mathrm{TN} \mathrm{g}^{-1}$ of tissue. The homogenate was then centrifuged at $1800 \times$ $g$ for $20 \mathrm{~min}$ and the supernatant filtered through a $0.45 \mu \mathrm{m}$ polyethersulfone (PES) filter (Whatman Pura$\left.\operatorname{disc}^{\circledR}\right)$. The stock inoculum was divided into $1.5 \mathrm{ml}$ aliquots, stored in liquid nitrogen, and served as the viral source for the $\mathrm{LD}_{50}$ assays.

Small inoculum preparations were necessary for viral amplification and negative control preparation. A similar protocol was used except the tissues were finely minced and homogenized using a $15 \mathrm{ml}$ tissue grinder (Wheaton) instead of a blender. The cuticle was also removed to prevent immobilization of the pestle in the tissue grinder. Negative control inocula were prepared in this manner utilizing cephalothorax tissues from uninfected shrimp derived from the same cohort as those used in the respective $\mathrm{LD}_{50}$ assay. All dilution dosages were expressed in grams of tissue $\mathrm{ml}^{-1}$ of TN buffer. 
Inoculum preparation for waterborne assays: Cephalothorax tissues of infected shrimp were diluted with chilled sterile $2 \%$ saline to a final concentration of $0.3 \mathrm{~g}$ tissue $\mathrm{ml}^{-1}$ saline. The mixture was homogenized for three $30 \mathrm{~s}$ intervals in a blender, with the homogenate placed on ice between intervals. The homogenate was filtered through 4 layers of sterile cheesecloth to remove large tissue particles, and centrifuged for $30 \mathrm{~min}$ at $3000 \times \mathrm{g}$ at $4^{\circ} \mathrm{C}$ to further remove small debris. The supernatant was passed through an $18 \mu \mathrm{m}$ nylon filter and frozen in $1.5 \mathrm{ml}$ aliquots at $-80^{\circ} \mathrm{C}$. Negative control inocula were prepared for each assay as described above from uninfected shrimp derived from the same cohort as the $\mathrm{LD}_{50}$ assay. All dilution dosages were expressed as grams of initial tissue used per volume (ml) of $2 \%$ saline.

Controlled bioassay system. The system utilizes $260 \mathrm{ml}$ tissue culture flasks (Nunclon ${ }^{\mathrm{TM}}$ ) containing 100 to $150 \mathrm{ml}$ of artificial seawater (Marine Environment ${ }^{\circledR}$ ). A $2 \mathrm{~mm}$ hole was drilled into the top upper right corner of the flask to permit air exchange. Individual shrimp were placed in the flasks and allowed to acclimate for $48 \mathrm{~h}$, then exposed to virus either by injection or by addition of virus-infected water. For injection assays, each individual was injected at a rate of $0.02 \mathrm{ml}$ of diluted inoculum $\mathrm{g}^{-1}$ of body weight, intramuscularly between the second and third tail segment. For waterborne assays, shrimp were exposed to challenge water for 24 or $48 \mathrm{~h}$, after which the challenge water was exchanged for standard artificial seawater. Aseptic techniques were used to prevent contamination between treatments. Water exchange (100\%) was performed daily throughout the trial. Screens were placed at the opening of the flasks to prevent the loss of challenged shrimp when exchanging water. A small piece of commercial shrimp diet pellet was placed in each flask following water exchange for the duration of the experiment. However, individuals were not fed $24 \mathrm{~h}$ p.i. Shrimp were observed and mortality recorded for 7 d. The $\mathrm{LD}_{50}$ was estimated using the US Environmental Protection Agency (EPA) Probit Analysis Program, Version 1.5. Student's $t$-test was used to evaluate differences between trials. Alpha level was set to 0.05 for all statistical tests. The probit lines were plotted as log dose +10 against mortality probability. Ten (10) was added to all log dose values to place the probit line in the positive quadrant.

Confirmation of viral infection: Infected shrimp were placed in Davidson's fixative (330 ml absolute

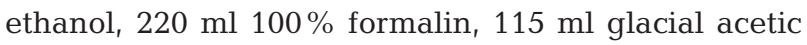
acid and $335 \mathrm{ml}$ distilled water) overnight and kept in $70 \%$ alcohol for H\&E histological examination and in situ hybridization (Lightner 1996). Gills and pleopods were also collected and placed in 90 to $95 \%$ ethanol for PCR detection.
Injection assays: TSV injection assay: A stock inoculum (TSV-A) for use in the TSV LD 50 injection assays was prepared and stored at a concentration of 1:10 expressed in grams of tissue $\mathrm{ml}^{-1} \mathrm{TN}$. The standard injection rate was $0.02 \mathrm{ml} \mathrm{g}^{-1}$ of shrimp body weight. Preliminary injection assays using exponential serial dilutions were performed to determine the range of inoculum dilutions for the $\mathrm{LD}_{50}$ determination. For TSV, dilutions from 1:10 through 1:1 $\times 10^{9}$ were tested to determine the range of concentration that would span 10 to $90 \%$ mortality. Based on the results of these assays, viral inoculum dilutions were set at 1:10 $\times 10^{6}$, $1: 40 \times 10^{6}, 1: 70 \times 10^{6}$ and $1: 100 \times 10^{6}$

WSSV injection assay: Preliminary assays using exponential dilutions between 1:500 000 and 1:8 $\times 10^{7}$ were conducted. Two stock inocula were prepared at 1:500 000 dilution (WSSV-A) and 1:10 (WSSV-B); 2 trials (Trials 1 and 2) were run for each inoculum using a dilution series of $1: 1 \times 10^{6}, 1: 4 \times 10^{6}, 1: 7 \times 10^{6}$ and 1:10 $\times 10^{6}$. WSSV-B was prepared from an amplification using WSSV-A inoculum.

Negative controls for both WSSV and TSV were run at a concentration of 1:10. All treatment groups for WSSV and TSV injection assays consisted of at least 20 shrimp.

Waterborne assays: Preliminary assays were performed using tissue homogenates from uninfected shrimp to determine the tolerance limits of test animals to organic matter in the water $(\mathrm{n}=10)$. Concentrations of $1: 2.5 \times 10^{3}, 1: 1.25 \times 10^{3}$ and 1:0.833 $\times 10^{3}$ were tested.

TSV waterborne assay: A large amount of stock TSV inoculum was required for each waterborne trial. Several aliquots of stock inoculum were thawed, combined, mixed thoroughly to ensure uniform concentration of viral material, and held at $4{ }^{\circ} \mathrm{C}$. The final dilutions of challenge water were prepared by combining appropriate proportions of positive or negative inoculum with artificial seawater $\left(30 \mathrm{ppt}, 20\right.$ or $27^{\circ} \mathrm{C}$ ) in 91 carboys. The challenge water was thoroughly mixed and $100 \mathrm{ml}$ was placed in each test flask. The exposure periods to challenge water were set at $24 \mathrm{~h}$, after which water was exchanged using clean artificial seawater.

Two stock inocula (TSV-B and TSV-C) were prepared for TSV waterborne assays. Two trials (Trials 1 and 2) were conducted using the TSV-B stock preparation. Dilutions between 1:10 × $10^{3}$ and $1: 3.333 \times 10^{3}$ were used in Trial 1 and dilutions between 1:20 $\times 10^{3}$ and $1: 2.353 \times 10^{3}$ were used in the second trial (see Table 3 ). The negative control doses for Trials 1 and 2 were $1: 3.333 \times 10^{3}$ and $1: 2.353 \times 10^{3}$, respectively. Both trials were conducted at $20^{\circ} \mathrm{C}$. An additional test (Trial 3) was conducted wherein TSV-B and TSV-C were diluted and a bioassay was conducted at $27^{\circ} \mathrm{C}$ (see Table 4). The negative control dose for Trial 3 was $1: 2.222 \times 10^{3}$. 

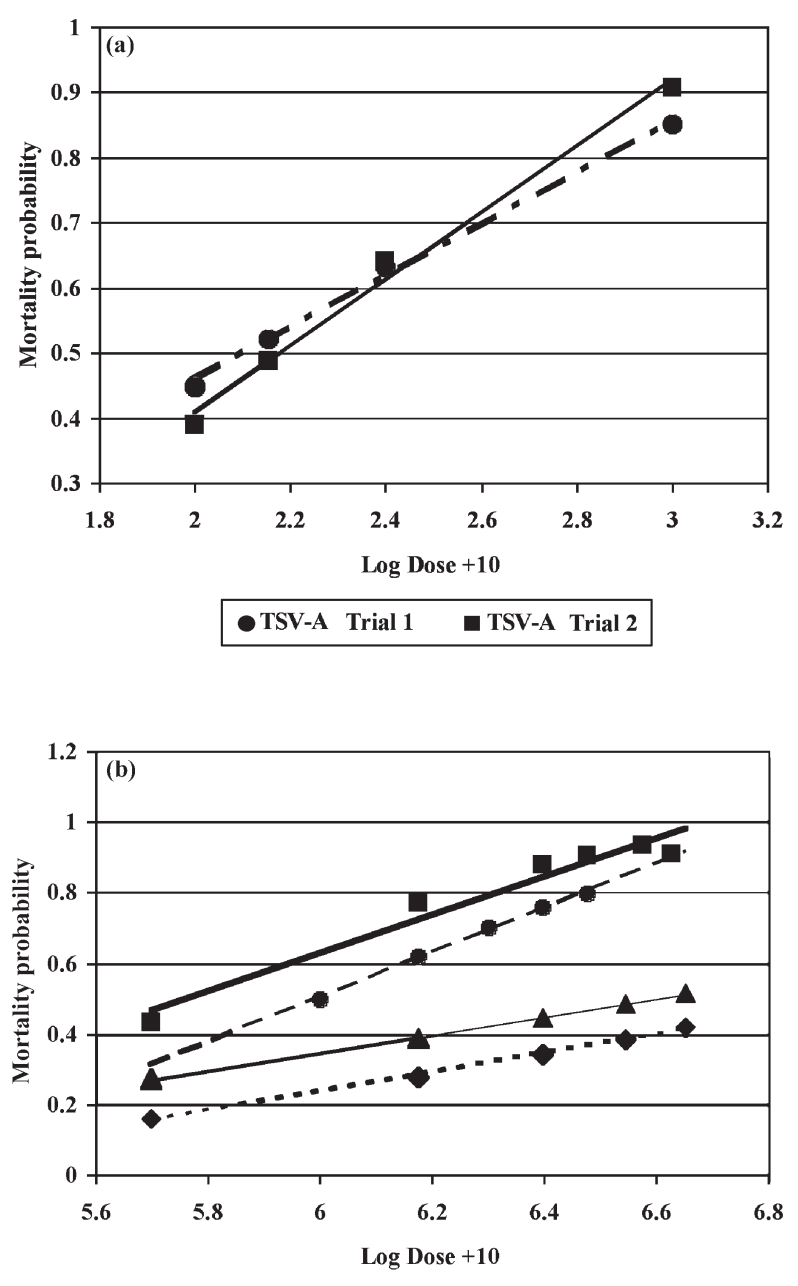

- TSV-B Trial 1 a TSV-B Trial $2 \diamond$ TSV-B Trial $3 \Delta$ TSV-C Trial 3

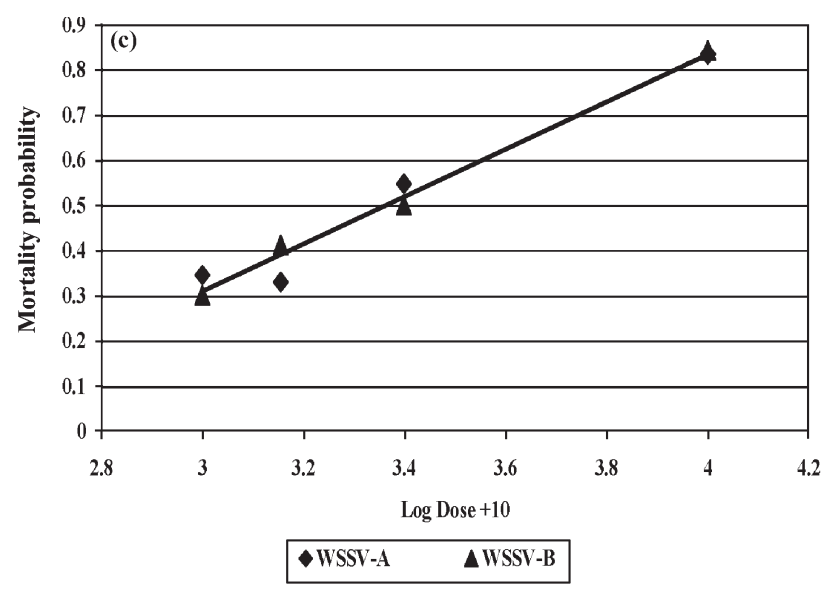

Fig. 1. Probit lines comparing bioassay response of Litopenaeus vannamei: (a) 2 challenge trials with TSV-A inoculum via injection, (b) challenge with 2 inocula (TSV-B and TSV-C) via the waterborne technique at $20^{\circ} \mathrm{C}$ (Trials 1 and 2) and $27^{\circ} \mathrm{C}$ (Trial 3), and (c) challenge with 2 WSSV inocula (WSSV-A and WSSV-B) via injection
WSSV waterborne assay: Concentrations of 1:2.857 $\times$ $10^{3}, 1: 1.428 \times 10^{3}$ and $1: 0.952 \times 10^{3}$ were assayed at both 24 and $48 \mathrm{~h}$ exposure at $27^{\circ} \mathrm{C}$ using $1 \mathrm{~g}$ individuals. Negative controls were run at the same concentrations for all trials using uninfected shrimp.

All treatment groups for WSSV and TSV waterborne assays consisted of at least 38 shrimp.

\section{RESULTS}

Injection assays

TSV injection assay

Trials 1 and 2 using TSV-A inoculum were conducted and a comparison between the 2 trials was made to determine the repeatability of the injection assay. Mortalities are reported in Table 1. No mortality was observed in the negative control group of either trial. Daily water exchange is critical for maintaining water quality in the flasks. Attempts to reduce water exchange to every $2 \mathrm{~d}$ resulted in increased mortality of the control group especially among molting or stressed individuals. A summary of the probit values is recorded in Table 2 and the probit lines are plotted in Fig. 1a. The chi-squared $\left(\chi^{2}\right)$ values for Trial $1(p>0.05)$ and Trial 2 ( $\mathrm{p}>0.90)$ indicated a good fit with the Probit analysis model. The $\mathrm{LD}_{50}$ was $1: 76.9 \times 10^{6}$ for Trial 1 and $1: 66.7 \times 10^{6}$ for Trial 2 . There was no significant difference between the $\mathrm{LD}_{50} \mathrm{~s}$ of Trials 1 and 2 (TSV-A) as indicated by Student's $t$-test $(p=0.59)$.

\section{WSSV injection assay}

Two WSSV inocula (WSSV-A and WSSV-B) were prepared in a similar manner to compare if there was a

Table 1. Percent mortality of Litopenaeus vannamei challenged with TSV and WSSV using injection bioassay methods

\begin{tabular}{|lcc|}
\hline TSV & $\begin{array}{c}\text { Trial 1 } \\
\text { Mortality (\%) }\end{array}$ & $\begin{array}{c}\text { Trial 2 } \\
\text { Mortality (\%) }\end{array}$ \\
\hline $1: 100 \times 10^{6}$ & 31 & 33 \\
$1: 70 \times 10^{6}$ & 61 & 57 \\
$1: 40 \times 10^{6}$ & 68 & 62 \\
$1: 10 \times 10^{6}$ & 85 & 90 \\
WSSV & WSSV-A & WSSV-B \\
& Mortality (\%) & Mortality (\%) \\
\hline $1: 10 \times 10^{6}$ & 34 & 30 \\
$1: 7 \times 10^{6}$ & 33 & 41 \\
$1: 4 \times 10^{6}$ & 55 & 50 \\
$1: 1 \times 10^{6}$ & 83 & 84 \\
\hline
\end{tabular}


Table 2. Probit analysis summary for Litopenaeus vannamei challenged with TSV and WSSV using injection and waterborne bioassay methods. LD: lethal dose

\begin{tabular}{|ccccccc|}
\hline & Inoculum & Trial & LD $_{50}$ & LD $_{90}$ & Slope & Sample size per treatment \\
\hline Injection & & & & & & $6-16$ \\
TSV (at $20^{\circ} \mathrm{C}$ ) & TSV-A & 1 & $1: 76.9 \times 10^{6}$ & $1: 6.33 \times 10^{6}$ & 1.18 & 21 \\
WSSV (at $20^{\circ} \mathrm{C}$ ) & WSSV-A & 1 & $1: 4.44 \times 10^{6}$ & $1: 6.18 \times 10^{5}$ & 1.49 & $58-72$ \\
Waterborne & WSSV-B & 2 & $1: 4.51 \times 10^{6}$ & $1: 6.21 \times 10^{5}$ & 1.49 & $40-57$ \\
TSV (at $20^{\circ} \mathrm{C}$ ) & TSV-B & 1 & $1: 9.92 \times 10^{3}$ & $1: 1.87 \times 10^{3}$ & 1.78 & 40 \\
TSV (at $27^{\circ} \mathrm{C}$ ) & & 2 & $1: 15.7 \times 10^{3}$ & $1: 3.45 \times 10^{3}$ & 1.95 & 40 \\
& TSV-B & 3 & $1: 1.27 \times 10^{3}$ & $1: 36.0$ & 0.83 & $44-49$ \\
& TSV-C & 3 & $1: 2.86 \times 10^{3}$ & $1: 31.6$ & 0.67 & $46-50$ \\
\hline
\end{tabular}

significant difference between the 2 preparations. Mortalities are reported in Table 1 . No mortality was observed in the negative control group for both trials. The $\mathrm{LD}_{50}$ was $1: 4.44 \times 10^{6}$ for WSSV-A and $1: 4.51 \times 10^{6}$ WSSV-B (Table 2).

The Probit lines for both trials were parallel to one another (Fig. 1c). The chi-squared $\left(\chi^{2}\right)$ values indicated a good fit with the Probit analysis model for WSSV-A $(p>0.30)$ and WSSV-B $(p>0.70)$. There was no significant difference between the 2 inocula under the test conditions (Student's $t$-test, $\mathrm{p}=1.00$ ).

\section{Waterborne assays}

\section{Preliminary waterborne assay}

In the preliminary exposure trials using negative control tissue homogenates, shrimp tolerated concentrations of $1: 2.5 \times 10^{3}$ and $1: 1.25 \times 10^{3}$ with no mortality observed. At 1:0.833 $\times 10^{3}, 100 \%$ mortality was observed.

\section{TSV waterborne assay}

Two inocula (TSV-B and TSV-C) were prepared for TSV waterborne assays. For TSV-B, 3 trials (Trials 1, 2 and 3) were conducted.

The mortalities for Trial 1 and Trial 2 using the TSV$\mathrm{B}$ inoculum are reported in Table 3 . The Probit lines are plotted in Fig. $1 \mathrm{~b}$ and a summary of the Probit values are listed in Table 2. Mortality of $4 \%$ was observed in the negative control of Trial 1 and $3 \%$ in Trial 2. The $\chi^{2}$ values for Trial $1(p>0.30)$ and Trial $2(p>0.70)$ indicated a good fit with the Probit analysis model. The $\mathrm{LD}_{50}$ s were $1: 9.92 \times 10^{3}$ and $1: 15.7 \times 10^{3}$, respectively (Table 2). There was a significant difference between the $\mathrm{LD}_{50} \mathrm{~s}$ of Trials 1 and 2 (Student's $t$-test, $\mathrm{p}=0.001$ ).
Table 3. Percent mortality of Litopenaeus vannamei challenged with TSV using waterborne bioassay methods at $20^{\circ} \mathrm{C}$

\begin{tabular}{|ccrc|}
\hline \multicolumn{2}{|c}{ Trial 1 } \\
Dilution & MSV-B) & \multicolumn{2}{c|}{ Trial 2 (TSV-B) } \\
& Mortality (\%) & Dilution & Mortality (\%) \\
\hline $1: 10 \times 10^{3}$ & 45 & $1: 20 \times 10^{3}$ & 43 \\
$1: 6.667 \times 10^{3}$ & 65 & $1: 6.667 \times 10^{3}$ & 80 \\
$1: 5 \times 10^{3}$ & 80 & $1: 4 \times 10^{3}$ & 88 \\
$1: 4 \times 10^{3}$ & 70 & $1: 3.333 \times 10^{3}$ & 88 \\
$1: 3.333 \times 10^{3}$ & 78 & $1: 2.667 \times 10^{3}$ & 95 \\
& & $1: 2.353 \times 10^{3}$ & 93 \\
\hline
\end{tabular}

Table 4. Percent mortality of Litopenaeus vannamei challenged with TSV using waterborne bioassay methods at $27^{\circ} \mathrm{C}$

\begin{tabular}{|ccc|}
\hline \multicolumn{1}{l}{ Dilution } & $\begin{array}{c}\text { TSV-B } \\
\text { Mortality (\%) }\end{array}$ & $\begin{array}{c}\text { TSV-C } \\
\text { Mortality (\%) }\end{array}$ \\
\hline $1: 20 \times 10^{3}$ & 21 & 23 \\
$1: 6.667 \times 10^{3}$ & 17 & 50 \\
$1: 4 \times 10^{3}$ & 37 & 42 \\
$1: 2.857 \times 10^{3}$ & 32 & 43 \\
$1: 2.222 \times 10^{3}$ & 51 & 52 \\
\hline
\end{tabular}

Table 5. Percent mortality of Litopenaeus vannamei challenged with WSSV using waterborne bioassay methods at $27^{\circ} \mathrm{C}$

\begin{tabular}{|lcc|}
\hline Dilution & $\begin{array}{c}\text { 24 h exposure } \\
\text { Mortality (\%) }\end{array}$ & $\begin{array}{c}\text { 48 h exposure } \\
\text { Mortality (\%) }\end{array}$ \\
\hline $1: 2.857 \times 10^{3}$ & 18 & 20 \\
$1: 1.428 \times 10^{3}$ & 20 & 39 \\
$1: 0.952 \times 10^{3}$ & 36 & 36 \\
\hline
\end{tabular}

In Trial 3, TSV-B and TSV-C were run concurrently. The mortalities produced by the 2 inocula are reported in Table 4. The mortality rate of the control dose $\left(1: 2.222 \times 10^{3}\right)$ was zero. In Trials 1 and 2 , the inoculum was added to seawater at room temperature $\left(20^{\circ} \mathrm{C}\right)$, whereas in Trial 3 the water was at $27^{\circ} \mathrm{C}$. The $\mathrm{LD}_{50}$ of 
TSV-B changed from 1:9.92 $\times 10^{3}$ and 1:15.7 $\times 10^{3}$ in Trials 1 and 2, respectively, to $1: 127 \times 10^{3}$ in Trial 3 (Table 2). The $\mathrm{LD}_{50}$ of the TSV-C was $1: 2.86 \times 10^{3}$. The probit lines are shown in Fig. $1 \mathrm{~b}$ and $\chi^{2}$ values showed a good fit to the Probit model $(p>0.10)$. There was a significant difference between the $\mathrm{LD}_{50} \mathrm{~S}$ of the TSV-B and TSV-C inocula in Trial 3 (Student's $t$-test, $\mathrm{p}=0.02$ ).

\section{WSSV waterborne assay}

No mortality was observed in the negative control groups at any concentration or incubation period. A summary of the results is given in Table 5. The mortality rates were too low to determine the $\mathrm{LD}_{50}$.

\section{Confirmation of viral infection}

Fresh dead animals collected during the assays displayed pathognomonic lesions typical of WSSV or TSV infections. No viral infections were detected in the negative control. Histological examination of moribund and dead individuals from TSV-infected groups demonstrated multifocal to diffuse necrosis of cuticular epithelium, with no definitive viral inclusions observed. Histological sections of fresh dead individuals from WSSV-infected groups confirmed the presence of large basophilic granular viral inclusions in nuclei of epithelial cells of the gastric, antennal gland epithelium, and cuticle. Inclusions were also noted in hematopoietic cells. No significant histological lesions were observed in tissues or organs from any specimen in the negative control groups.

\section{DISCUSSION}

The controlled bioassay systems for TSV and WSSV presented in this paper offer important advantages compared to conventional shrimp bioassay methods. Isolating test individuals in separate flasks, rather than holding shrimp in 1 tank, eliminates the possibility of viral dose magnification via cannibalism and the shedding of infective virions through the culture medium. Although the tissue flask system is laborious and costintensive, the ability to challenge shrimp with a uniform viral dose under relatively uniform environmental regimes provides an important experimental tool.

Due to the inherent variability of this type of in vivo challenge system, standardization of treatment conditions and use of similar size experimental shrimp are essential to achieve reproducible results. These trials led to the standardization of shrimp size (1.00 \pm $0.25 \mathrm{~g})$, challenge volume $(100 \mathrm{ml})$ and sample size
(40 test animals). In the injection experiments, results showed no significant difference between trials and inoculum regardless of the source of the infected material, or the concentration at which the amplified material is stored. The $2 \mathrm{WSSV}$ injection inocula produced similar mortality in relation to dose even though the inocula originated from different amplifications and stock inocula, and were frozen at different concentrations. However, results are based on only 2 trials, and further tests will have to be made before conclusions can be drawn.

In general, environmental factors such as temperature can have a profound effect on the infective lethal doses of viral pathogens. Temperature has been shown to affect susceptibility of Penaeidae to TSV (Jimenez et al. 2000), WSSV (Chou et al. 1995) and other viral diseases (Goarant et al. 2000). Although the present study was not designed to provide a concurrent controlled comparison of temperature effects, clear trends could be discerned. The first TSV waterborne inoculum initially produced $\mathrm{LD}_{50} \mathrm{~S}$ of $1: 9.92 \times 10^{3}$ and $1: 15.7 \times 10^{3}$ at $20^{\circ} \mathrm{C}$ (Trials 1 and 2, respectively). In the third trial, the $\mathrm{LD}_{50}$ of the same inoculum changed dramatically $\left(1: 1.27 \times 10^{3}\right)$ when the temperature of the challenge water increased to $27^{\circ} \mathrm{C}$. It is possible that the differences in $\mathrm{LD}_{50}$ and $\mathrm{LD}_{90}$ values calculated for the TSV-B inoculum at 20 and $27^{\circ} \mathrm{C}$ are due to the effect of temperature. This is consistent with the analysis of TSV epizootics in Ecuador, where there was a negative correlation between TSV prevalence and temperature (Jimenez et al. 2000). However, more data are required to confirm the possible relationship between dose and temperature.

Environmental factors such as temperature must be controlled in comparative bioassay studies to assure repeatability of results. Challenge temperature has been indicated as an important variable affecting the relative virulence of WSSV (Vidal et al. 2001). The dramatic change in the $\mathrm{LD}_{50}$ of the TSV inoculum relative to changes in temperature reiterates the importance of standardization of challenge conditions and protocols. Comparative trials should be conducted utilizing a standardized inoculum to minimize potential for variation between trials.

The slopes in all of the trials were low producing a relatively flat line indicating low response homogeneity among test subjects. This is characteristic of viral dose response curves (Knight 1965). However, low slope characteristics allow a margin of error with regard to dose, because a large change in dose is required to change the response. The dose used in a trial must only reach within the range of the $50 \%$ mark to provide data for treatment comparisons.

The response of shrimp to alternative modes of viral introduction under controlled bioassay conditions can 
provide important information relevant to controlling disease in culture environments. More controlled comparisons may improve current understanding of factors governing infectivity of free virions in water and susceptibility to waterborne versus per os or carrier-mediated infection. The present study was not designed to provide a carefully controlled concurrent challenge of a single cohort of shrimp to compare waterborne and injection assays. Different methods were used for filtration of waterborne and injection inocula. Nevertheless, clear differences in the response of the shrimp were observed. For example, the results of the waterborne challenge showed more variability than the injection trials. This may be due to the lack of control of viral uptake by the test animals. In injection trials, a known volume of prepared inoculum is injected into the shrimp, whereas using the waterborne challenge method, an unknown quantity of virus is absorbed.

Low mortality levels observed in the WSSV waterborne trials did not allow for $\mathrm{LD}_{50}$ and $\mathrm{LD}_{90}$ determination. With the current system configuration, $260 \mathrm{ml}$ flasks and $1.0 \mathrm{~g}$ shrimp, homogenate doses are limited to less than 1:833 according to negative control trials. Although the potency of the WSSV waterborne inoculum was verified in a subsequent injection assay (Prior et al. unpubl. results), the highest mortality seen in the waterborne challenge was $39 \%$. Itami et al. (1998) reported on the effects of waterborne challenge of Marsupenaeus japonicus held in containers downstream from WSSV-infected shrimp. The results varied between trials in that severe mortality began 3 or $25 \mathrm{~d}$ following exposure, ultimately reaching 80 or $75 \%$ mortality after 30 or 40 d, respectively. Chou et al. $(1995,1998)$ reported $100 \%$ mortality for Penaeus monodon, M. japonicus and $P$. penicillatus postlarvae within $6 \mathrm{~d}$ of exposure to $0.45 \mu \mathrm{m}$ filtered homogenates of epidermal tissue from naturally WSSV-infected $P$. monodon and $M$. japonicus. For $M$. japonicus a clear effect of size was demonstrated with mortality rates decreasing from $35 \%$ in $0.16 \mathrm{~g}$ shrimp after $7 \mathrm{~d}$ to $10 \%$ mortality in $0.26 \mathrm{~g}$ juveniles after $2 \mathrm{wk}$ (Chou et al. 1995). Shrimp in these studies were held in tanks together, which possibly amplifies the dose by viral shedding of cohabitants. These authors also reported increased mortality rates in immersion assays following temperature or capture stress. The relative resistance of $1 \mathrm{~g}$ juveniles to waterborne challenge to a set dose of WSSV could have important ramifications in a culture environment. For example, field observations suggested that a strategy based on the maintenance of susceptible postlarve in a WSSV-free environment to a larger size before stocking into ponds in affected areas could improve production success (Samocha et al. 2000). Further research will be necessary to explore the modes of infection and pathogenesis of these viruses to help explain these differences.

One aspect which must be explored in future studies is the disease status of assay survivors, particularly when tissue homogenates are heavily diluted prior to inoculation. More detailed studies will be needed to determine if survivors were exposed to viable infective virus and if so how infection was controlled. RT-PCR analysis of pleopods from 24 TSV $\mathrm{LD}_{50}$ injection survivors yielded 4 positives, while only 1 pleopod of 29 was positive for WSSV LD ${ }_{50}$ injection survivors (Prior et al. unpubl. results). The $7 \mathrm{~d}$ duration of these trials was sufficient to demonstrate high levels of mortality with increasing initial dose in the injection assays and continuation of the trials over several additional days resulted in little if any additional mortality. For the waterborne assay, however, extending the observation time may yield different results. These bioassay methods provide a model to begin the search for new innovative approaches to environmental assessment, husbandry and selective breeding of farmed species, disease control, and reliable robust diagnostics for aquatic diseases.

Acknowledgements. This research was funded by the USDA/CSRS US Marine Shrimp Farming Program and NOAA-NMFS (\#NA97FL0377). This is publication number 505 from the South Carolina Division of Marine Resources.

\section{LITERATURE CITED}

Brock JA (1992) Current diagnostic methods for agents and diseases of farmed marine shrimp. In: Fulks W, Main KL (eds) Diseases of cultured penaeid shrimp in Asia and the United States. The Oceanic Institute, Honolulu, HI, p 209-231

Brock JA, Main KL (1994) A guide to the common problems and diseases of cultured Penaeus vannamei. World Aquaculture Society, Baton Rouge, LA

Brock JA, Gose R, Lightner DV, Hasson K (1995) An overview on Taura Syndrome, an important disease of farmed Penaeus vannamei. In: Browdy CL, Hopkins JS (eds) Swimming through troubled water. Proc Special Session on Shrimp Farming. Aquaculture '95, World Aquaculture Society, Baton Rouge, LA, p 84-94

Chen SN, Kou GH (1989) Infection of cultured cells from the lymphoid organ of Penaeus monodon Fabricius by monodon-type baculovirus (MBV). J Fish Dis 12:73-76

Chou HY, Huang CY, Wang CH, Chiang, HC, Lo CF (1995) Pathogenicity of a baculovirus infection causing white spot syndrome in cultured penaeid shrimp in Taiwan. Dis Aquat Org 23:165-173

Chou HY, Huang CY, Lo CF, Kou GH (1998) Studies on the transmission of white spot syndrome associated baculovirus (WSBV) in Penaeus monodon and P. japonicus via waterborne contact and oral injestion. Aquaculture 164: 263-276

Durand SV, Tang KFJ, Lightner DV (2000) Frozen commodity shrimp: potential avenue for introduction of white spot syndrome virus and yellow head virus. J Aquat Anim 
Health 12:128-135

Fulks W, Main KL (1992) Diseases of cultured penaeid shrimp in Asia and the United States. The Oceanic Institute, Honolulu, HI

Goarant C, Herlin J, Brizard R, Marteau A-L, Martin C, Martin B (2000) Toxic factor of Vibro strains pathogenic to shrimp. Dis Aquat Org 40:101-107

Itami T, Asano M, Tokushige $\mathrm{K}$, Kubono K and 6 others (1998) Enhancement of disease resistance of kuruma shrimp, Penaeus japonicus, after oral administration of peptidoglycan derived from Bifidobacterium thermophilum. Aquaculture 164:277-288

Jimenez R, Barniol R, de Barniol L, Machuca M (2000) Periodic occurrence of epithelial viral necrosis outbreaks in Penaeus vannamei in Ecuador. Dis Aquat Org 42:91-99

Kasornchandra J, Boonyaratpalin S (1998) Primary shrimp cell culture: applications for studying white spot syndrome virus (WSSV). In: Flegel TW (ed) Advances in shrimp biotechnology. National Center for Genetic Engineering and Biotechnology, Bangkok, p 273-276

Knight GJ (1965) Measurement of virus infectivity. Statistician 15:43-57

Lightner DV (1996) A handbook of shrimp pathology and diagnostic procedures for diseases of cultured penaeid shrimp. World Aquaculture Society, Baton Rouge, LA

Lightner DV (1999) The penaeid shrimp viruses TSV, IHHNV, WSSV, and YHV: current status in the Americas, available diagnostic methods, and management strategies. J Appl Aquacult 9:27-52

Lightner DV, Redman RM (1991) Hosts, geographic range, and diagnostic procedures for the penaeid virus diseases of concern to shrimp culturists in the Americas. In: DeLoach PK, Dougherty WJ, Davidson MA (eds) Frontiers of shrimp research. Elsevier, Amsterdam, p 173-196

Lightner DV, Redman RM (1998) Shrimp diseases and current diagnostic methods. Aquaculture 164:201-220

Lightner DV, Redman RM, Williams RR, Mahoney LL, Clerix JPM, Bell TA, Brock JA (1985) Recent advances in penaeid virus disease investigations. J World Maricult Soc 16: 267-274

Lightner DV, Tang-Nelson K, Durand SV, Redman RM, Mohney LL (2001) Qualitative and quantitative studies on the relative virus load of tails and heads of shrimp acutely infected with WSSV. In: Browdy CL, Jory DE (eds) The new wave. Proceedings of the special session on sustainable shrimp farming. World Aquaculture Society, Baton Rouge, LA, p 285-291

Loh PC, Cesar E, Nadala Jr. B, Tapay LM, Lu Y (1998) Recent developments in immunologically based and cell culture protocols for the specific detection of shrimp viral pathogens. In: Flegel TW (ed) Advances in shrimp biotechnology. National Center for Genetic Engineering and Biotechnology, Bangkok, p 255-260

Lu Y, Tapay LM, Loh PC, Brock JA (1995a) Infection of the yellow head baculo-like virus in two species of penaeid

Editorial responsibility: Timothy Flegel,

Bangkok, Thailand shrimp, $P$. stylirostris and $P$. vannamei. J Fish Dis 17: 649-656

Lu Y, Tapay LM, Loh PC, Brock JA, Gose RB (1995b) Distribution of yellow head virus in selected tissues and organs of penaeid shrimp Penaeus vannamei. Dis Aquat Org 23: $67-70$

Momoyama K, Sano T (1988) A method of experimental infection of kuruma shrimp larvae, Penaeus japonicus Bate, with baculoviral mid-gut gland necrosis (BMN) virus. J Fish Dis 11:105-111

Overstreet RM, Stuck KC, Krol RA, Hawkins WE (1988) Experimental infection with Baculovirus penaei in the white shrimp Penaeus vannamei (Crustacea, Decapoda) as a bioassay. J World Aquacult Soc 19:175-187

Overstreet RM, Lightner DV, Hasson KW, McIlwain S, Lotz JM (1997) Susceptibility to Taura Syndrome Virus of some penaeid shrimp species native to the Gulf of Mexico and the Southeastern United States. J Invertebr Path 69: 165-176

Plumb JA (1999) Health maintenance and principal microbial diseases of cultured fishes. Iowa State University Press, Ames

Poulos BT, Pantoja CR, Bradley-Dunlop D, Aguilar J, Lightner DV (2001) Development and application of monoclonal antibodies for the detection of whitespot syndrome virus of penaeid shrimp. Dis Aquat Org 47:13-23

Samocha TM, Blancher T, Cordova J, de Wind A (2000) Raceway nursery production increases survival and yields in Ecuador. Global Aquacult Advocate 3(6):66-68

Sindermann CJ (1986) The role of pathology in aquaculture. In: Bilio M, Rosenthal H, Sindermann CJ (eds) Realism in aquaculture: achievements, constraints, perspectives. European Mariculture Society, Bredene, Belgium, p 319-419

Tang KFJ, DV Lightner (2000) Quantification of white spot syndrome virus DNA through a competitive polymerase chain reaction. Aquaculture 189:11-21

Vidal OM, Granja CB, Brock JA, Salazar M (2001) A profound effect of hyperthermia on the survival of Litopenaeus vannamei juveniles infected with white spot syndrome virus. In: Browdy CL, Jory DA (eds) The new wave. Proceedings of the special session on sustainable shrimp farming. World Aquaculture Society, Baton Rouge, LA, p 362

Wang Q, White BL, Redman RM, Lightner DV (1999) Per os challenge of Litopenaeus vannamei postlarvae and Farfantepenaeus duorarum juveniles with six geographic isolates of white spot syndrome virus. Aquaculture 170: 179-194

Wyban JA, Swingle JS, Sweeney JN, Pruder GD (1992) Development and commercial performance of high health shrimp using specific pathogen free (SPF) broodstock Penaeus vannamei. In: Wyban J (ed) Proceedings of the special session on shrimp farming. World Aquaculture Society, Baton Rouge, LA, p 254-260

Submitted: April 19, 2002; Accepted: November 21, 2002

Proofs received from author(s): March 14, 2003 